\title{
Antioxidant potential of Pfaffia glomerata and Arrabidaea chica extracts combination
}

\author{
Potencial antioxidante da combinação do extrato de Pfaffia glomerata com extrato de Arrabidaea \\ chica
}

Potencial antioxidante de la combinación de extractos de Pfaffia glomerata y Arrabidaea chica

Received: 03/22/2021 | Reviewed: 03/30/2021 | Accept: 04/02/2021 | Published: 04/12/2021

\author{
Lucas Dutra Zani da Silva Souza \\ ORCID: https://orcid.org/0000-0001-5662-5382 \\ Universidade Cesumar, Brasil \\ E-mail: zanidutrass@gmail.com \\ Ariana Ferrari \\ ORCID: https://orcid.org/0000-0001-7843-8019 \\ Universidade Cesumar, Brasil \\ E-mail: ariana.ferrari@unicesumar.edu.br \\ Daniele Fernanda Felipe \\ ORCID: https://orcid.org/0000-0001-9028-0728 \\ Universidade Cesumar, Brasil \\ E-mail: daniele.felipe@unicesumar.edu.br
}

\begin{abstract}
Several therapeutic benefits of medicinal plants are attributed to antioxidant properties, since antioxidant compounds play an important role in the prevention of various diseases and aging. Many products have synergistic action from combinations of plant extracts that contain natural antioxidants. The present study aimed to evaluate the synergistic effect of Pfaffia glomerata extract with Arrabidaea chica extract for antioxidant action. In the study the extract of the inflorescences of $P$. glomerata and the extract of the leaves of $A$. chica were used. The synergism between $P$. glomerata extract and A. chica extract was evaluated using the ratio between experimental and theoretical antioxidant activity, which was determined using the DPPH method and the potential total reactive antioxidant method (TRAP). The combination of $P$. glomerata extract and A. chica extract showed a synergistic effect, in which the antioxidant property of this combination was substantially superior to the sum of the individual antioxidant effects. This demonstrates that the combined extracts can be important for the development of products that have a high antioxidant potential.
\end{abstract}

Keywords: Brazilian ginseng; Pariri; Antioxidant activity; Synergism.

\section{Resumo}

Vários benefícios terapêuticos das plantas medicinais são atribuídos às propriedades antioxidantes, uma vez que compostos antioxidantes apresentam um papel importante na prevenção de várias doenças e do envelhecimento. Muitos produtos apresentam ação sinérgica de combinações de extratos vegetais que contêm antioxidantes naturais. $\mathrm{O}$ presente estudo teve como objetivo avaliar o efeito sinergista da combinação do extrato de Pfaffia glomerata com extrato de Arrabidaea chica quanto à ação antioxidante. No estudo foram utilizados o extrato das inflorescências da $P$. glomerata e o extrato das folhas de A. chica. O sinergismo entre o extrato de $P$. glomerata e extrato de $A$. chica foi avaliado usando a proporção entre atividade antioxidante experimental e teórica, a qual foi determinada usando o método DPPH e o método potencial antioxidante reativo total (TRAP). A combinação do extrato de $P$. glomerata e extrato de A. chica mostrou um efeito sinérgico, em que a propriedade antioxidante desta combinação foi substancialmente superior à soma dos efeitos antioxidantes individuais. Isto demonstra que os extratos combinados podem ser importantes para o desenvolvimento de produtos que tenham alto potencial antioxidante.

Palavras-chave: Ginseng brasileiro; Pariri; Atividade antioxidante; Sinergismo.

\section{Resumen}

Varios beneficios terapéuticos de las plantas medicinales se atribuyen a las propiedades antioxidantes, ya que los compuestos antioxidantes juegan un papel importante en la prevención de diversas enfermedades y el envejecimiento. Muchos productos tienen una acción sinérgica a partir de combinaciones de extractos de plantas que contienen antioxidantes naturales. El presente estudio tuvo como objetivo evaluar el efecto sinérgico del extracto de Pfaffia glomerata con el extracto de Arrabidaea chica con respecto a su acción antioxidante. En el estudio se utilizó el extracto de las inflorescencias de $P$. glomerata y el extracto de las hojas de $A$. chica. El sinergismo entre el extracto de $P$. glomerata y el extracto de A. chica se evaluó mediante la relación entre la actividad antioxidante experimental y teórica, que se determinó mediante el método DPPH y el método antioxidante reactivo total potencial (TRAP). La 
combinación de extracto de $P$. glomerata y extracto de $A$. chica mostró un efecto sinérgico, en el que la propiedad antioxidante de esta combinación fue sustancialmente superior a la suma de los efectos antioxidantes individuales. Esto demuestra que los extractos combinados pueden ser importantes para el desarrollo de productos que tienen un alto potencial antioxidante.

Palabras clave: Ginseng brasileiro; Pariri; Actividad antioxidante; Sinergismo.

\section{Introduction}

Reactive oxygen species are common free radicals that are known to cause damage to lipids, proteins, carbohydrates, and nucleic acids, causing cell or tissue damage that is manifested in various disorders, including cancer, Parkinson's disease, atherosclerosis, cardiovascular disease, disease inflammatory, and aging (Radi, 2018; Vellosa et al., 2021). Oxidation reactions can produce free radicals that initiate chain reactions that can damage skin cells, leading to the appearance of wrinkles, photoaging, elastosis, dryness and skin pigmentation (Kusumawati and Indrayanto, 2013).

Through the action of antioxidants, it is possible to neutralize the free radicals responsible for the oxidation of cells, which lead to premature aging. The antioxidant can delay or prevent oxidation, promoting protection of the body's cells against the oxidizing action of free radicals (Lima, Santana and Moreira, 2018). The human body has an endogenous antioxidant mechanism that includes several enzymes and non-enzymatic antioxidants (Kaim and Backes, 2019). In addition to the natural production of endogenous antioxidants, there are exogenous sources that can be acquired through diet or through topical use (de Freitas et al., 2020).

Plants have some of the most potent natural antioxidants and are widely used for their antioxidant and anti-aging effects (Kalim, Bhattacharyya, Banerjee, and Chattopadhyay, 2010). In addition, the consumption of natural antioxidants has been associated with a lower incidence of diseases related to oxidative stress (de Azevedo et al., 2020). One of the current objectives in industrial research is the search for natural antioxidants for food, cosmetics and pharmaceutical inputs (Alves and Souza, 2020). These three sectors promote such products, which are referred to as functional foods, food supplements, nutraceuticals and cosmeceuticals (Peschel et al., 2006). Many patents and commercial cosmetic products feature various combinations of plant extracts that contain natural antioxidants (Kusumawati and Indrayanto, 2013).

Pfaffia glomerata (Spreng.) Pedersen (Amaranthaceae), known as Brazilian ginseng, is widely used in Brazil to treat various pathological conditions (Franco et al., 2021). Studies report that $P$. glomerata extract is widely used in the pharmaceutical industry, due to its antimicrobial, anti-rheumatic, anti-tumor, anti-diabetic properties, in addition to actions such as anti-inflammatory, healing and antioxidant effect (Silva et al., 2010; Oliveira and Sakai, 2020; Souza, Fonseca, Ferrari, and Felipe, 2021).

A Korean company has registered two patents for cosmetics containing $P$. glomerata along with other active ingredients. The patent KR1116447 reported that a cosmetic that contains extract from the roots of $P$. glomerata, arginine salt of L-pyrrolidone carboxylic acid (PCA arginine), Melia azedarach extract and yeast extract as active components, can increase the cell dynamics of the skin, prevent the appearance of wrinkles, lighten and moisturize the skin, in addition to relieving skin problems (Lee et al., 2012). The patent KR1155180 presented an anti-aging cosmetic containing extract from the roots of $P$. glomerata and PCA arginine, which inhibits damage to neurocytes in the skin, in addition to inhibiting damage to fibroblasts and keratinocytes caused by ultraviolet radiation (Gang et al., 2012).

The main component of Pfaffia glomerata is $\beta$-ecdysone, a phytoecdysteroid, found in the roots, stem, inflorescences and leaves of the plant (Oliveira and Sakai, 2020; Serra, Felipe, and Cortez, 2012; Souza, Fonseca, Ferrari, and Felipe, 2021). Many pharmacological effects are attributed to $\beta$-ecdysone, one of which is the antioxidant action (Lafont; Dinan, 2003; Daniel et al., 2005). Research by Nsimba, Kikuzaki, and Konishi (2008), showed that ecdysteroids, including $\beta$-ecdysone, can be considered effective compounds to prevent or delay skin damage related to collagenase and oxidative stress. In addition to 
these actions, Dinan and Lafont (2006) reported that $\beta$-ecdysone has wound healing and skin regenerating activity. The US5609873 patent determines the use of ecdysteroids, mainly $\beta$-ecdysone, for dermatological and cosmetic preparations, because $\beta$-ecdysone strengthens the water barrier function of the skin, increases keratinocyte differentiation, and gives the skin a smoother and softer appearance (Meybeck, Bonte, and Redziniak, 1997).

In addition to ecdysteroids, which have been considered natural antioxidants, many investigations have revealed that phenolic compounds and flavonoids also contribute to the antioxidant activity of plants (Cai, Luo, Sun, and Corke, 2004; Zhang et al., 2011). The flavonoids are widely used in the cosmetic, medicine and food industries, due to their antioxidant properties, with application in anti-aging products (Henrique and Lopes, 2017). These compounds were identified in the inflorescences of P. glomerata in a study carried out by Felipe et al., (2014), which showed that the main compounds identified, in addition to $\beta$-ecdysone, were glycosylated flavonoids, such as quercetin-3-O-glycoside, kaempferol-3-Oglycoside and kaempferol-3-O-(6-pcumaryl)-glycoside, which are important bioactive compounds for use in phytotherapy and in the cosmetics industry.

A study carried out by Henrique and Lopes (2017), showed the increasing use of biodiversity, for the development of new cosmetic assets that can act effectively against skin aging, highlighting the importance of flavonoids. These compounds are used clinically in cosmetic formulations for oral or topical use, since they provide protection to the skin against harmful endogenous and exogenous agents, and enable the prevention and treatment of skin disorders, in addition to preventing aging.

Studies demonstrate that there is a positive correlation between antioxidant activity and flavonoid content, indicating that these types of polyphenols could be the main responsible for the antioxidant activity observed in various plant extracts (Jiménez-Estrada et al., 2013). For example, studies have shown that the extract of Arrabidaea chica Verlot. (Bignoniaceae) has significant antioxidant activity, which could be attributed to the presence of the mixture of flavonoids in the plant extract, mainly scutellarin and apigenin (Siraichi et al., 2013). Other studies have reported that A. chica extract has healing and antiinflammatory properties, antifungal activity and antitumor activity (Jorge et al., 2008; Barbosa et al., 2008; Ribeiro et al., 2012). The patent PI0703095 reported a pharmaceutical formulation containing A. chica for photoprotection and pigmentation (Dias Filho et al., 2009).

The A. chica plant, popularly known as "Pariri", is a shrub that is present in tropical America, particularly in the Amazon Basin, and has been grown in Southern Brazil (Barbosa et al., 2008; Siraichi et al., 2013). Several studies have determined the content of phenolic compounds and flavonoids in the leaves of A. chica, which is the part used in folk medicine (Silva et al., 2007; Barbosa et al., 2008; Siraichi et al., 2013).

In phytotherapy, greater efficacy can be achieved with the application of a combination of plant extracts than with generally high doses of an individual extract. This association at the same time has the advantage of reducing or eliminating side effects due to the lower doses of the compounds present in the mixture of extracts (Wagner, 2006). Some combinations of compounds exhibit synergistic interactions, while others show additive interactions, and still others show antagonistic interactions (Kirakosyan et al., 2010).

Therapeutic synergism has been described for several plant extracts (Williamson, 2001). For example, a combination of kava (Piper methysticum) and valerian (Valeriana officinalis) appears to be better for the treatment of stress-induced insomnia than the use of these plants individually (Wheatley, 2001). Studies have reported synergistic interactions between natural antioxidants (Liu et al., 2008). Fuhrman, Volkova, Rosenblat, and Aviram, (2000) found that a combination of different antioxidants is superior to the action of an individual antioxidant in protecting low-density lipoprotein (LDL) against oxidation.

The synergistic action of combinations of antioxidant extracts in lower concentrations can be a strategy for the cosmetic and food industries (Beddows, Jagait, and Kelly, 2001; Peschel et al., 2006). The study of natural substances with 
strong antioxidant potential that can act alone or synergistically with other additives has emerged as an alternative to the use of synthetics due to sustainability, ease of obtaining and economic viability (Massarolo et al., 2017; Wróblewska, Baby, Guaratini, and Moreno, 2019).

The choice of appropriate active plant extracts, confirmation of their activity, and synergistic effects are important factors when developing effective products (Kusumawati and Indrayanto, 2013). Thus, the present study aimed to evaluate the synergistic effect of the extract of $P$. glomerata in combination with the extract of $A$. chica, regarding the antioxidant action.

\section{Methodology}

\subsection{Plant material}

In the present research, the extract of the inflorescences of P. glomerata and the extract of the leaves of A. chica were used, which were acquired from the Laboratory in Natural Products and Biotechnology, located at the State University of Maringá, Maringá, Paraná. The extract of the inflorescences of P. glomerata obtained was standardized in the study carried out by Souza, Fonseca, Ferrari, and Felipe, (2021), which was prepared from the plant collected in Querência do Norte, Paraná, Brazil (in the month of April, at 9:00 a.m. approximately, transported in a closed package), and presented $\beta$ - ecdysone (91.35 $\mu \mathrm{g} / \mathrm{mL}$ ) as a major compound.

The A. chica leaf extract was standardized in the study by Siraichi et al., (2013). The standardized extract was obtained from the plant cultivated in Southern Brazil, collected in the month of February, at 9:00 a.m. approximately, and it was transported in a closed package to protect from moisture. The plant contained a mixture of flavonoids, mainly scutellarein $(818.6 \mu \mathrm{g} / \mathrm{ml})$ and apigenin $(112.04 \mu \mathrm{g} / \mathrm{ml})$, in addition to other minor flavonoids, such as isoscutellarein, 6-hydroxyluteolin, hispidulin, and luteolin.

\subsection{Antioxidant assays for calculation of synergism}

The antioxidant activity of the $P$. glomerata inflorescence extract alone was compared with the combination with the A. chica leaf extract to evaluate the synergistic effect of this combination. The antioxidant activity of the P. glomerata extract, A. chica extract, and a combination of their extracts were determined using the DPPH radical scavenging assay and total reactive antioxidant potential (TRAP) method. The experiments were performed in triplicate.

\subsubsection{DPPH radical scavenging assay}

The DPPH radical scavenging capacity was determined according to the procedure of Brand-Willians, Cuvelier, and Berset (1995). From stock solutions prepared in methanol at a concentration of $100 \mu \mathrm{g} / \mathrm{ml}$, the P. glomerata inflorescence extract and A. chica leaf extract were diluted at concentrations of 75 and $7.5 \mu \mathrm{g} / \mathrm{ml}$, respectively, which are the concentrations of the two extracts in combination that produce a $50 \%$ antioxidant effect $\left(\mathrm{IC}_{50}\right)$, calculated as described below.

An aliquot ( $3 \mathrm{ml}$ ) of sample solution was mixed thoroughly with $300 \mu \mathrm{l}$ of DPPH solution and then left for $30 \mathrm{~min}$ at room temperature in the dark. The absorbance of the solutions was measured at $515 \mathrm{~nm}$ against a blank ( $3 \mathrm{ml}$ sample solution and $300 \mu \mathrm{l}$ methanol) using a spectrophotometer. Three replicates were made for each test sample. A methanolic solution that contained $3 \mathrm{ml}$ methanol and $300 \mu \mathrm{l}$ of the DPPH solution was used as a negative control. The DPPH radical scavenging activity (\%) was calculated using the following equation described by Scherer and Godoy (2009):

\footnotetext{
Scavenging activity $(\%)=\left[\left(\mathrm{Abs}_{0}-\mathrm{Abs}_{1}\right) / \mathrm{Abs}_{0}\right] \times 100$
} 
where $\mathrm{Abs}_{0}$ is the absorbance of the negative control, and $\mathrm{Abs}_{1}$ is the absorbance in the presence of the extract. The scavenging ability of the extracts is expressed as the $\mathrm{IC}_{50}$ value, which is the concentration of the sample that is required to scavenge $50 \%$ of DPPH free radicals. The $\mathrm{IC}_{50}$ values were calculated using linear regression plots, in which the ordinate represents the scavenging activity $(\%)$, and the abscissa represents the concentration of the tested extracts.

\subsubsection{TRAP method}

The TRAP method was performed as described in vivo by Repetto et al., (1996) and reproduced in vitro by Ghiselli, Serafini, Natella, \& Scaccini (2000) e Pellegrini et al., (2003). This technique evaluates the levels of total antioxidants. In this method, ABAP was used as a generator system for peroxyl radicals by thermal decomposition, producing photons that were amplified and measured by a TD 20/20 luminometer via a chemiluminescence reaction. The reaction was inhibited by analogs of vitamin $\mathrm{E}$ (Trolox), which was used as an antioxidant standard.

The antioxidant activity of the individual extracts and their combination was analyzed. The $P$. glomerata inflorescence extract at a concentration of $0.33 \mu \mathrm{g} / \mathrm{ml}$, A. chica leaf extract at the same concentration, and these extracts combined at a dose ratio of 1:1 were mixed with $200 \mathrm{mM}$ luminol and $200 \mathrm{mM}$ ABAP to a final volume of $1 \mathrm{ml}$. The TRAP of these samples was calculated using the following equation:

$$
\operatorname{TRAP}(\mu \mathrm{M} \text { Trolox })=(\text { Tind } \text { sample } \mu \mathrm{M} \text { Trolox }) / \text { Tind } \text { Trolox }
$$

where Tind represents the induction time for which the antioxidant produces peroxyl formation/number of photons readings in $1 \mathrm{~min}$. The TD20/20 luminometer detects chemiluminescence at a wavelength of 300-650 nm, has $50.1 \%$ sensitivity, and can produce 450-12,500 readings. The luminometer was connected to a computer through Spreadsheet Interface v. 1.0 software to record the chemiluminescence emission. Origin v. 8.0 software was used to plot chemiluminescence curves.

\subsection{Calculation of synergism between Pfaffia glomerata extract and Arrabidaea chica extract}

The synergistic effects of combinations of the P. glomerata extract with the A. chica extract were based on the ratio between experimental antioxidant activity (EAA) and theoretical antioxidant activity (TAA). The EAA of the extracts in combination was calculated using the equations previously described for the DPPH method and TRAP method. Theoretical antioxidant activity is the sum of the antioxidant activity of each extract. For the DPPH method, TAA was calculated using the following equation described by Fuhrman, Volkova, Rosenblat, and Aviram (2000):

$$
\% \mathrm{TAA}=(\mathrm{A}+\mathrm{B})-(\mathrm{A} \times \mathrm{B} / 100)
$$

where A is the percent EAA of the individual $P$. glomerata extract, and B is the percent EAA of the individual A. chica extract. Synergistic effects were calculated using the following equation described by Fuhrman, Volkova, Rosenblat, and Aviram (2000):

$$
\text { Synergistic effect }=\text { EAA } / \text { TAA }
$$

where synergism is shown when the synergistic effect is $>1$. 


\subsection{Statistical analysis}

All of the experiments were performed at least in triplicate, and the results are expressed as mean \pm standard deviation (SD). In the antioxidant assays, the data were compared using analysis of variance (ANOVA) followed by Tukey's test. For the synergism analysis, Student's $t$-test was performed to compare the two means (EAA and TAA). The level of significance was set at $5 \%$, and differences were considered statistically significant at $p<0.05$. The statistical analysis was performed using GraphPad Prism v. 5.0 software (GraphPad, San Diego, CA, USA).

\section{Results and Discussion}

To investigate the synergism between the $P$. glomerata inflorescence extract and A. chica leaf extract, the antioxidant activity of the single extracts and their combination was examined. We focused primarily on these extracts because of their relatively high antioxidant capacities, which was reported in the research by Souza, Fonseca, Ferrari, and Felipe, (2021) for $P$. glomerata and in the study by Siraichi et al., (2013) for A. chica.

The antioxidant activity of single extracts, determined by the DPPH method and TRAP method, is presented in Tables 1 and 2. The TRAP method, similar to the DPPH method, indicates the free radical scavenging ability of antioxidants via the hydrogen atom transfer pathway, but against peroxyl radicals (Ghiselli, Serafini, Natella, and Scaccini, 2000). The antioxidant capacity of the A. chica extract was higher than the $P$. glomerata extract using both methods. This may be explained by the fact that the A. chica extract presents a high content of flavonoids, which are the major constituents that contribute to antioxidant activity in most plants and act as an effective scavenger of free radicals (Siraichi et al., 2013; Jiménez-Estrada et al., 2013).

Based on the data obtained from the single extracts, the TAA of the extracts in combination was calculated, in addition to EAA, to examine synergistic effects (Tables 1 and 2). If the EAA is greater than the TAA, then an interaction is evident among the antioxidants, thus displaying synergism. Mathematically, a ratio of EAA/TAA > 1 would indicate a synergistic effect (Liu et al., 2008). Considering the antioxidant activity determined by the DPPH method (Table 1), a significant $(p<0.05)$ synergistic effect $(1.17)$ was produced by the combination of the P. glomerata extract and A. chica extract. The EAA and TAA values were $51.7 \pm 1.72 \%$ and $44.2 \pm 1.60 \%$, respectively, whereas the antioxidant activity of the P. glomerata extract alone was $20.9 \pm 0.66 \%$, indicating that the EAA of the extracts in combination exceeded the TAA by $17 \%$.

Table 1. Synergistic effect (SE) of the P. glomerata extract with A. chica extract, considering the antioxidant activity determined by the DPPH method.

\begin{tabular}{|c|c|c|c|c|}
\hline \multirow[b]{2}{*}{ Extract concentration } & \multirow{2}{*}{$\begin{array}{l}\text { Extract alone } \\
\text { \% Antioxidant } \\
\text { activity }^{\text {a }}\end{array}$} & \multicolumn{3}{|c|}{ Extracts in combination $(P$. glomerata $+A$. chica $)$} \\
\hline & & \% TAA ${ }^{\mathbf{a}}$ & $\% \mathbf{E A A}^{\mathrm{a}}$ & $\mathbf{S E}^{\mathbf{b}}$ \\
\hline P. glomerata $75 \mu \mathrm{g} / \mathrm{ml}$ & $20.9 \pm 0.66$ & & & \\
\hline A. chica $7.5 \mu \mathrm{g} / \mathrm{ml}$ & $29.4 \pm 0.82$ & $44.2 \pm 1.60$ & $51.7 \pm 1.72$ & $1.17 *$ \\
\hline
\end{tabular}

Theoretical antioxidant activity (TAA) was calculated from data for the extracts alone. The asterisk denote a significant difference compared

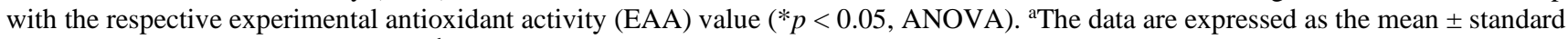
deviation of triplicate measurements. ${ }^{\text {b }} \mathrm{SE}>1$ : synergistic effect shown.

Source: Authors (2021). 
Based on the antioxidant activity evaluated by the TRAP method (Table 2), the combined extracts also exhibited a significant $(p<0.05)$ synergistic effect $(1.25)$, with an EAA value of $2.44 \pm 0.28 \mu \mathrm{M}$ Trolox and TAA value of $1.95 \pm 0.14 \mu \mathrm{M}$ Trolox. The $P$. glomerata extract alone had antioxidant activity of $0.65 \pm 0.15 \mu \mathrm{M}$ Trolox, indicating that the EAA of the combination of the extracts exceeded the TAA by $25.1 \%$.

Table 2. Synergistic effect (SE) of the P. glomerata extract with A. chica extract, considering the antioxidant activity determined by the TRAP method.

\begin{tabular}{|c|c|c|c|c|}
\hline \multirow[b]{2}{*}{ Extract concentration } & \multirow{2}{*}{$\begin{array}{c}\text { Extract alone } \\
\text { Antioxidant activity } \\
(\mu \mathrm{M} \text { Trolox })^{\mathbf{a}}\end{array}$} & \multicolumn{3}{|c|}{ Extracts in combination $(P$. glomerata $+A$. chica $)$} \\
\hline & & $\mathbf{T A A}(\mu \mathrm{M} \text { Trolox })^{\mathbf{a}}$ & $\mathbf{E A A}(\mu \mathrm{M} \text { Trolox })^{\mathbf{a}}$ & $\mathbf{S E}^{\mathbf{b}}$ \\
\hline P. glomerata $0.33 \mu \mathrm{g} / \mathrm{ml}$ & $0.65 \pm 0.15$ & & & \\
\hline A. chica $0.33 \mu \mathrm{g} / \mathrm{ml}$ & $1.30 \pm 0.13$ & $1.95 \pm 0.14$ & $2.44 \pm 0.28$ & $1.25 *$ \\
\hline
\end{tabular}

Theoretical antioxidant activity (TAA) was calculated from data for the extracts alone. The asterisk denote a significant difference compared with the respective experimental antioxidant activity (EAA) value $\left(* p<0.05\right.$, ANOVA). ${ }^{*}$ The data are expressed as the mean \pm standard deviation of triplicate measurements. ${ }^{\text {b }} \mathrm{SE}>1$ : synergistic effect shown.

Source: Authors (2021).

Fuhrman, Volkova, Rosenblat, and Aviram (2000) reported that lycopene acts synergistically with several natural antioxidants as an effective antioxidant against LDL oxidation. They showed that when the lycopene was combined with rosmarinic acid or vitamin E, the inhibition of LDL oxidation, measured as TBARS formation, also exceeded the expected additive inhibition of the individual antioxidants by $17 \%$ and $25 \%$, respectively. A study carried out by de Souza, Correa, Silva \& Conceição (2021), showed that plant extracts containing natural antioxidants combined with synthetic antioxidants showed synergism, in other words, the mixture of each tested extract with the synthetic antioxidant presented a better performance than used individually.

Several plant extracts have been shown to exhibit synergistic interactions (Williamson, 2001). Scholey and Kennedy (2002) studied the synergism between different extracts in a product that contained Panax ginseng extract with Ginkgo biloba extract, which was demonstrated to be more effective in improving cognitive function than the extracts alone. A study by Capasso and Sorrentino [69] used a standardized extract combination of Kava-Kava and Passiflora, and the superiority of the combination over the individual extracts in a sedative and hypnotic test was found. They observed an approximately 50\% higher efficacy of the extract combination compared with the individual extracts. In the present study, the results showed $59.6 \%$ higher antioxidant activity of the combination of $P$. glomerata and A. chica compared with the $P$. glomerata extract alone using the DPPH method, and 73.4\% higher antioxidant activity was found using the TRAP method.

The present study found evidence that the $P$. glomerata extract acts synergistically with the $A$. chica extract, in which the combined extracts had effective DPPH and peroxyl radicals scavenging activity. Previous studies reported that only compounds with strong antioxidant capacities exhibit synergistic interactions (Kirakosyan et al., 2010). Liu et al., (2008) showed that specific concentrations and combinations of antioxidants were more effective than the corresponding individual antioxidants in scavenging DPPH. They reported that the synergistic effect appeared to be partially based on the reducing potential of the various antioxidants and their ability to convert antioxidant free radicals to their native form. 
Flavonoids may play a role in increasing the biological activity of other compounds through synergistic mechanisms (Williamson, 2001). Thus, these compounds that according Siraichi et al., (2013), are present at high concentrations in A. chica leaves, could have contributed to the synergistic effects observed between the combined extracts, once that interaction may have occurred between flavonoids and $\beta$-ecdysone, which is the major compound in P. glomerata inflorescences. Additionally, synergistic interactions may be explained by enhanced absorption, metabolism and reduced excretion or by enhanced effectiveness at the target site(s) of action (Kirakosyan et al., 2010). In the case of flavonoids, they likely affect membrane lipid viscosity or protein movement (Tarahovsky, Muzafarov, \& Kim, 2008).

The general understanding of synergism is that combinations of substances have greater effects than the substances alone. This can apply to an increased therapeutic effect, reduced side-effect profile at low doses, or both. Synergistic interactions are important in phytomedicine for constituents within a total extract of a single herb and between different herbs in a formulation (Williamson, 2001). The present work demonstrated that the combined extracts can be an alternative for the development of products that have high antioxidant potential. O uso de tais produtos é uma estratégia interessante para combater o estresse oxidative que frequentemente é associado ao envelhecimento precoce e ao surgimento de diversas doenças crônicas (de Moraes, Ferreira, Souza, and Moreira, 2020). In addition to antioxidant substances, there is a great trend in the cosmetic industry in the development of multifunctional cosmetics that also combine moisturizing and photoprotective substances, and synergistic effects can be obtained from many combinations (Gaspar, Camargo, Gianeti, and Campos, 2008).

\section{Conclusion}

The present study demonstrates that the $P$. glomerata inflorescence extract acted synergistically with the $A$. chica leaf extract, with effective antioxidant capacity, suggesting that these extracts in combination offer great potential for the prevention of photoaging and diseases associated with oxidative stress. Additionally, the effects of the extracts combined may be important for the development of multifunctional cosmetics, in which the mixture of the extracts could combine the antioxidant ability with other beneficial effects on the skin, such as the moisturizing property of the P. glomerata extract and photoprotective activity of the A. chica extract. These effects could improve skin conditions and promote healthier skin.

\section{Acknowledgments}

The authors thank to Master Program in Clean Technologies and to ICETI - Cesumar Institute of Science, Technology and Innovation.

\section{References}

Alves, J. M., \& Souza, A. O. (2020). O perfil antioxidante no ritmo circadiano de Jambos malaccensis, Ocimum gratissimum e Astrocaryum aculeatum. Revista Ensino, Saúde e Biotecnologia da Amazônia, 2(1), 19-28.

Azevedo, S. S., Mesquita, G. P., Mendes, Y. C., Costa, G. D. E., da Silva, L. C. N., \& Zagmignan, A. (2020). Avaliação da atividade antioxidante de chás comercializados em feiras livres e de chás industrializados em São Luís-Maranhão, Brasil. Research, Society and Development, 9(8), e06985320-e06985320.

Barbosa, W. L. R., Pinto, L. D. N., Quignard, E., Vieira, J. M. D. S., Silva Jr, J. O. C., \& Albuquerque, S. (2008). Arrabidaea chica (HBK) Verlot: phytochemical approach, antifungal and trypanocidal activities. Revista Brasileira de Farmacognosia, 18(4), $544-548$.

Beddows, C. G., Jagait, C., \& Kelly, M. J. (2001). Effect of ascorbyl palmitate on the preservation of $\alpha$-tocopherol in sunflower oil, alone and with herbs and spices. Food Chemistry, 73(3), 255-261.

Brand-Williams, W., Cuvelier, M. E., \& Berset, C. L. W. T. (1995). Use of a free radical method to evaluate antioxidant activity. LWT-Food science and Technology, 28(1), 25-30.

Cai, Y., Luo, Q., Sun, M., \& Corke, H. (2004). Antioxidant activity and phenolic compounds of 112 traditional Chinese medicinal plants associated with anticancer. Life sciences, 74(17), 2157-2184. 
Capasso, A., \& Sorrentino, L. (2005). Pharmacological studies on the sedative and hypnotic effect of Kava kava and Passiflora extracts combination. Phytomedicine, 12(1-2), 39-45.

Daniel, J. F. S., Alves, K. Z., Jacques, D. S, Souza, P. D. S., de Carvalho, M. G., Freire, R. B., Ferreira, D. T., \& Freire, M. F. (2005). Free radical scavenging activity of Pfaffia glomerata (Spreng.) Pederson (Amaranthaceae). Indian journal of pharmacology, 37(3), 174

Dias Filho, B. P., Nakamura, C. V., Cortez, D. A. G., Siraichi, J. T. G., Serra, L. Z., Puhl, C. M. N., \& Nakamura, T. U. (2009). Formulação farmacêutica à base da espécie vegetal Arrabidaea chica para fotoproteção e pigmentação. Brasil patent PI 0703095.

Dinan, L., \& Lafont, R. (2006). Effects and applications of arthropod steroid hormones (ecdysteroids) in mammals. Journal of Endocrinology, 191(1), 1-8.

Freitas, L. M. A., Gomes, B. C. R., Nascimento, C. F., Lage, I. L., Caricati, J. M. M. P., de Sena Silva, L. A., dos Santos, M.J.C., Silva, S.R.A., \& de Souza Almeida, V. L. (2020). Antioxidantes como forma de prevenção contra a ação dos radicais livres no processo de envelhecimento cutâneo. ÚNICA Cadernos Acadêmicos, 3(1). 1-10

Felipe, D. F., Brambilla, L. Z., Porto, C., Pilau, E. J., \& Cortez, D. A. (2014). Phytochemical analysis of Pfaffia glomerata inflorescences by LC-ESIMS/MS. Molecules, 19(10), 15720-15734

Franco, R. R., de Almeida Takata, L., Chagas, K., Justino, A. B., Saraiva, A. L., Goulart, L. R., Ávila, V. M. R., Otoni, W. C., Espindola, F. S., \& da Silva, C. R. (2021). A 20-hydroxyecdysone-enriched fraction from Pfaffia glomerata (Spreng.) pedersen roots alleviates stress, anxiety, and depression in mice. Journal of Ethnopharmacology, 267, 113599.

Fuhrman, B., Volkova, N., Rosenblat, M., \& Aviram, M. (2000). Lycopene synergistically inhibits LDL oxidation in combination with vitamin E, glabridin, rosmarinic acid, carnosic acid, or garlic. Antioxidants and Redox Signaling, 2(3), 491-506.

Gang, C.G., Cho, S.A., Kim, J.H., Jang, H.G., Cho, \& J.C. (2012). The cosmetic composition for sunscreen for the antiaging controlling the nerve cell damage due to the ultraviolet ray. Korea patent KR 1155180

Gaspar, L. R., Camargo Jr, F. B., Gianeti, M. D., \& Campos, P. M. (2008). Evaluation of dermatological effects of cosmetic formulations containing Saccharomyces cerevisiae extract and vitamins. Food and chemical toxicology, 46(11), 3493-3500.

Ghiselli, A., Serafini, M., Natella, F., \& Scaccini, C. (2000). Total antioxidant capacity as a tool to assess redox status: critical view and experimental data. Free Radical Biology and Medicine, 29(11), 1106-1114.

Henrique, A. D. S., \& Lopes, G. C. (2017). Biodiversidade e a indústria de cosméticos: O uso dos flavonóides contra o envelhecimento cutâneo. Revista Uningá Review, 29(2), 58-63.

Jiménez-Estrada, M., Velázquez-Contreras, C., Garibay-Escobar, A., Sierras-Canchola, D., Lapizco-Vázquez, R., Ortiz-Sandoval, C., Burgos-Hernández, A., \& Robles-Zepeda, R. E. (2013). In vitro antioxidant and antiproliferative activities of plants of the ethnopharmacopeia from northwest of Mexico. BMC complementary and alternative medicine, 13(1), 1-8.

Jorge, M. P., Madjarof, C., Ruiz, A. L. T. G., Fernandes, A. T., Rodrigues, R. A. F., de Oliveira Sousa, I. M., Foglio, M.A., \& de Carvalho, J. E. (2008), Evaluation of wound healing properties of Arrabidaea chica Verlot extract. Journal of Ethnopharmacology, 118(3), 361-366.

Kaim, M., \& Backes, L. T. H. (2019). Envelhecimento celular: teorias e mecanismos. Revista Saúde Integrada, 12(23), 178-189.

Kalim, M. D., Bhattacharyya, D., Banerjee, A., \& Chattopadhyay, S. (2010). Oxidative DNA damage preventive activity and antioxidant potential of plants used in Unani system of medicine. BMC Complementary and alternative medicine, 10(1), 1-11.

Kirakosyan, A., Seymour, E. M., Noon, K. R., Llanes, D. E. U., Kaufman, P. B., Warber, S. L., \& Bolling, S. F. (2010). Interactions of antioxidants isolated from tart cherry (Prunus cerasus) fruits. Food Chemistry, 122(1), 78-83.

Kusumawati I., \& Indrayanto G. (2013). Natural antioxidants in cosmetics. Studies in Natural Products Chemistry, 40, 485-505.

Lafont, R., \& Dinan, L. (2003). Practical uses for ecdysteroids in mammals including humans: and update. Journal of insect science, 3(1), 1-30.

Lee, C.G., Kim, J.Y., Jang, H.G., Min, D.J., \& Cho, J.C. (2012). The cosmetic composition for the dynamic activation of a skin cell. Korea patent KR 1116447.

Lima, A. F., de Jesus Santana, E. C., \& Moreira, J. A. R. (2018). Atuaça o da vinhoterapia no retardo do envelhecimento cuta neo: revisa o de literatura. Revista Científica da FHO v, 6(2), 1-18

Liu, D., Shi, J., Ibarra, A. C., Kakuda, Y., \& Xue, S. J. (2008). The scavenging capacity and synergistic effects of lycopene, vitamin E, vitamin C, and $\beta$ carotene mixtures on the DPPH free radical. LWT-Food Science and Technology, 41(7), 1344-1349.

Moraes, T. V., Ferreira, J. P. G., de Souza, M. R. A., \& Moreira, R. F. A. (2020). Atividade antioxidante e conteúdo de compostos fenólicos do chá do caule da Pereskia aculeata Miller fresco e armazenado sob congelamento. Research, Society and Development, 9(5), e34953140-e34953140.

Massarolo, K. C., de Souza, T. D., Collazzo, C. C., Furlong, E. B., \& de Souza Soares, L. A. (2017). The impact of Rhizopus oryzae cultivation on rice bran Gamma-oryzanol recovery and its antioxidant properties. Food chemistry, 228, 43-49.

Meybeck, A., Bonte, F., Redziniak, G. (1997). Use of an ecdysteroid for the preparation of cosmetic or dermatological compositions intended, in particular, for strengthening the water barrier function of the skin or for the preparation of a skin cell culture medium, as well as to the compositions. United States patent US5609873.

Nsimba, R. Y., Kikuzaki, H., \& Konishi, Y. (2008). Ecdysteroids act as inhibitors of calf skin collagenase and oxidative stress. Journal of biochemical and molecular toxicology, 22(4), 240-250. 
Oliveira, C. B. D., \& Sakai, O. A. (2020). Clean Technologies for Obtaining Biocomposites of Brazilian Ginseng Pfaffia glomerata (Spreng.) Pedersen: A Review. European Journal of Medicinal Plants, 31(14), 18-31.

Pellegrini, N., Serafini, M., Colombi, B., Del Rio, D., Salvatore, S., Bianchi, M., \& Brighenti, F. (2003). Total antioxidant capacity of plant foods, beverages and oils consumed in Italy assessed by three different in vitro assays. The Journal of nutrition, 133(9), 2812-2819.

Peschel, W., Sánchez-Rabaneda, F., Diekmann, W., Plescher, A., Gartzía, I., Jiménez, D., Lamuela-Raventós R., Buxaderas S., \& Codina, C. (2006). An industrial approach in the search of natural antioxidants from vegetable and fruit wastes. Food Chemistry, 97(1), 137-150.

Radi, R. (2018). Oxygen radicals, nitric oxide, and peroxynitrite: Redox pathways in molecular medicine. Proceedings of the National Academy of Sciences, 115(23), 5839-5848.

Repetto, M., Reides, C., Carretero, M. L. G., Costa, M., Griemberg, G., \& Llesuy, S. (1996). Oxidative stress in blood of HIV infected patients. Clinica Chimica Acta, 255(2), 107-117.

Ribeiro, A. F. C., Telles, T. C., Ferraz, V. P., Souza-Fagundes, E. M., Cassali, G. D., Carvalho, A. T., \& Melo, M. M. (2012). Effect of Arrabidaea chica extracts on the Ehrlich solid tumor development. Brazilian Journal of Pharmacognosy 22(2), 364-373.

Souza, D. A. A., da Luz Correa, A. P., da Silva, P. M. M., \& da Conceição, L. R. V. (2020). Avaliação do potencial de misturas de antioxidantes naturais e sintético na estabilidade oxidativa de biodiesel. Brazilian Journal of Development, 6(10), 74562-74578.

Scherer, R., \& Godoy, H. T. (2009). Antioxidant activity index (AAI) by the 2, 2-diphenyl-1-picrylhydrazyl method. Food chemistry, 112 (3), $654-658$.

Scholey, A. B., \& Kennedy, D. O. (2002). Acute, dose-dependent cognitive effects of Ginkgo biloba, Panax ginseng and their combination in healthy young volunteers: Differential interactions with cognitive demand. Human Psychopharmacology: Clinical and Experimental, 17(1), 35-44.

Serra, L.Z., Felipe, D.F., \& Cortez, D.A.G. (2012). Quantification of $\beta$-ecdysone in differents parts of Pfaffia glomerata by HPLC. Brazilian Journal of Pharmacognosy, 22(6), 1349-1354.

Silva, E. M., Souza, J. N. S., Rogez, H., Rees, J. F., \& Larondelle, Y. (2007). Antioxidant activities and polyphenolic contents of fifteen selected plant species from the Amazonian region. Food chemistry, 101(3), 1012-1018.

Silva, M. I., Ribas-Filho, O., Malafaia, O., Nassif, P. A. N., Ribas, M. M., Varaschim, M., \& Czeczko, L. E. (2010). A utilização da Pfaffia glomerata no processo de cicatrização de feridas da pele. Arquivos brasileiros de cirurgia digestiva, 23(4), 28-233.

Siraichi, J. T. G., Felipe, D. F., Brambilla, L. Z. S., Gatto, M. J., Terra, V. A., Cecchini, A. L., \& Cortez, D. A. G. (2013). Antioxidant capacity of the leaf extract obtained from Arrabidaea chica cultivated in Southern Brazil. PLoS One, 8(8), 1-9.

Souza, L. D. Z. D. S., Fonseca, S. R. A. V. D., Ferrari, A., \& Felipe, D. F. (2021). $\beta$-ecdysone content and antioxidant capacity in different organs of Brazilian ginseng. Ciência Rural, 51(5), 1-9.

Tarahovsky, Y. S., Muzafarov, E. N., \& Kim, Y. A. (2008). Rafts making and rafts braking: how plant flavonoids may control membrane heterogeneity. Molecular and cellular biochemistry, 314(1), 65-71.

Vellosa, J. C. R., Biavatti, M., Françóia, P. C. O., de Mello, B. J., de Almeida, A. C., \& Bueno, G. E. (2021). Estresse oxidativo: uma introdução ao estado da arte. Brazilian Journal of Development, 7(1), 10152-10168.

Wagner, H. (2006). Multitarget therapy-the future of treatment for more than just functional dyspepsia. Phytomedicine, 13, $122-129$.

Wheatley, D. (2001). Stress-induced insomnia treated with kava and valerian: singly and in combination. Human Psychopharmacology: Clinical and Experimental, 16(4), 353-356.

Williamson, E. M. (2001). Synergy and other interactions in phytomedicines. Phytomedicine, 8(5), 401-409.

Wróblewska, K. B., Baby, A. R., Guaratini, M. T. G., \& Moreno, P. R. H. (2019). In vitro antioxidant and photoprotective activity of five native Brazilian bamboo species. Industrial Crops and Products, 130, 208-215.

Zhang, L., Ravipati, A. S., Koyyalamudi, S. R., Jeong, S. C., Reddy, N., Smith, P. T., Bartlett, J., Shanmugam, K., Münch, D.G., \& Wu, M. J. (2011). Antioxidant and anti-inflammatory activities of selected medicinal plants containing phenolic and flavonoid compounds. Journal of agricultural and food chemistry, 59(23), 12361-12367. 